\title{
A Community-Based Intervention: Impact of an Educational Program in Exchanging Knowledge, Attitude, and Practices of Female Genital Mutilation (FGM)
}

Amal Ibrahim Khalii* and Abeer Mokhtar Orabi

King Saud Bin Abdelaziz University, Saudi Arabia

\begin{abstract}
Background: Female genital mutilation (FGM) is a form of gender-based violence and a violation of female human rights. Although much work has been done to tackle this practice in Egypt, UNICEF (2016) has reported that the prevalence of FGM remains high in Africa and the Middle East.
\end{abstract}

Aim: To investigate the effectiveness of an educational program at changing the knowledge, attitudes, and practices of school teachers towards FGM.

Methods: A quasi-experimental research design (one group pre/post) assessment was used, which included 30 female teachers selected from the AI Tonsi Primary School (mixed education: males and female) affiliated to the Ministry of Art and Education, Cairo, Egypt.

Results: The included 30 Egyptian teachers (mean age: $36.93 \pm 8.42$ years) had a mean of $1.47 \pm 0.0 .73$ daughters the majority of which were university graduates, grown up in urban areas, and were married $(80.0 \%, 73.3 \%$ and $86.6 \%$ respectively). Most of the respondents (86.7\%) were circumcised; $77 \%$ by traditional birth attendants. The mean total knowledge about FGM was $11.7 \pm 2.0 .0$ in the pre-test and increased to $27.4 \pm 1.3$ in the post-test $(P<0.001)$. The mean total score for attitude toward FGM practices was $43.9 \pm 6.8$ in the pre-test and $26.5 \pm 1.6$ in the post-test $(P<0.001)$ In the pretest, $20 \%$ of the respondents were willing to circumcise their daughters, with a significantly higher prevalence among teachers who grew up in urban areas $(66.7 \%)$ than in rural areas $(P<0.001)$. None of the respondents were willing to circumcise their daughters in the post-test. Significant correlations were detected between the age of the respondents and the total attitude score in the pretest $(P=0.002)$, the number of daughters, and the total attitude score in the pretest and posttest $(\mathrm{P}=0.03$ and $\mathrm{P}=0.01$, respectively).

Conclusions and recommendations: The educational program was effective at changing the knowledge, attitudes, and future practices of female teachers towards FGM. Therefore, addressing mothers through ongoing educational activities is needed to increase their awareness about the dangers of FGC and to change attitudes towards its continuation.

Keywords: Female genital mutilation; Educational program; Knowledge; Attitude; Practices

\section{Background}

One of the basic human rights is to live in a safe environment without any physical or psychological harm. Female genital mutilation (FGM) is a form of gender-based violence; it is known as an outdated risky practice and is considered as a violation of female human rights. The UNICEF reported that, at least 200 million women and girls across 30 countries have experienced such unsafe practice- where it is commonly exercised in Africa, Asia and the Middle East [1]. Nevertheless, reports were also provided in Europe, Australia and North America within diaspora communities. FGM demonstrated the highest prevalence in women and girls from Egypt and Ethiopia According to WHO FGM is described as "all procedures that involve partial or total removal of the external female genitalia, or other injury to the female genital organs for non-medical reasons" [1-3]. FGM practice has no health benefits but rather, consequences which affect all aspects of a female's life-including health and education. FGM can also act as a precursor to early/child marriage, which are also considered a violation of human rights and slavery in some situations Egypt, like many other developing countries, FGC remained a common practice which has traditionally been performed $[4,5]$. The most common forms of FGC still widely practiced throughout Egypt are type I (commonly referred to as clitoridectomy) and type II (commonly referred to as excision) [6]. There are many causes for performing FGM which may vary depending on cultural, social or regional factors [7]. A common identified reason of performing FGC is social norm which is the risk of social exclusion by the community. Accordingly, it was stated that FGM is a deeply rooted practice within a cultural context and tradition and is given as the main reasons for its continuation [8]. WHO, stated that the main reason for performing FGC is raising and preparing a girl for adulthood and marriage [7]. FGC is often driven by the belief that it reduces a woman's' libido and therefore minimizes risks of premarital intercourse and marital infidelity. According to UNICEF there is a correlation between educational level and practicing FGM since the daughters of uneducated mothers are more likely to be cut related to cultural ideals of femininity and modesty $[7,9]$. Therefore, engendering knowledge about the causes and effects of FGM and planning effective

*Corresponding author: Amal Ibrahim Khalil, King Saud Bin Abdelaziz University, Saudi Arabia, Tel: +966595138896; E-mail: khalila@ksau-hs.edu.sa

Received September 13, 2017; Accepted October 06, 2017; Published Octobe 13, 2017

Citation: Khalil Al, Orabi AM (2017) A Community-Based Intervention: Impact of an Educational Program in Exchanging Knowledge, Attitude, and Practices of Female Genital Mutilation (FGM). Health Care Current Reviews 5: 209. doi: 10.4172/23754273.1000209

Copyright: $\odot 2017$ Khalil Al, et al. This is an open-access article distributed unde the terms of the Creative Commons Attribution License, which permits unrestricted use, distribution, and reproduction in any medium, provided the original author and source are credited. 
policy interventions are strategies to eliminate FGM. Researchers have recently started to study FGM both from a theoretical point of view and empirically looking in particular at the determinants of FGM or at the effect of law or program interventions against FGM Nowak has said that "the pain inflicted by FGM does not stop with the initial procedure, but often continues as ongoing torture throughout a woman's life [10-18].

WHO has categorized four types of FGM, varying between partial to total removal of the external female $[19,20]$. Type I is called Clitoridectomy which performed by removing partial or total clitoris and/or the prepuce. Excision is a Type II performance which comprises partial or total removal of the clitoris and the labia minora, and is executed with or without an excision of the labia majora. With further concerns, Type III involves narrowing the vaginal orifice by cutting the labia minora and/or labia majora making it/them a covering seal. This type is executed with or without infibulation. On the other hand, Type IV includes all other harmful procedures done to the female genitalia for non-medical purposes such as: pricking, piercing, scraping or cutting. It was reported that, girls and women may not recognize what type of FGM they have undergone but there are a variety of short and long-term consequences associated with FGM. The practice can potentially have undesirable complications, including death. The shortterm complications include: pain, acute urinary retention, excessive bleeding, infection (including tetanus and transmission of blood borne viruses) [21-23]. While the long-term consequences include: pain (chronic neuropathic pain) keloid scarring, recurrent infection (urinary tract infections, increased incidence of certain genital infections), birth complications (postpartum hemorrhage, caesarean section) and sexual dysfunction [20]. In addition, certain psychological effects including depression, anxiety and post-traumatic stress disorder.

Although the prevalence of the practice has declined over the past 30 years, the rise in population growth, however, will mark a significant increase in the number of women and girls subjected to FGM over the next 15 years [1]. Reducing FGM is of global urgency and features within Sustainable Development Goal 5 ("Achieve gender equality and empower all women and girls") under target 5.3, which states: "Eliminate all harmful practices, such as child, early and forced marriage and female genital mutilation" [24]. Moreover, a study in Egypt demonstrated that the prevalence of FGM among female medical students was $14.7 \%$, with greater dominance among those from rural areas (25\%) [25]. However, a substantial decline in the prevalence of FGM has been reported from countries with the already low prevalence of the practice [26]. Furthermore, a study among medical students in Egypt indicated that $58.7 \%$ of female students had a favorable attitude towards discontinuation of the practice [27]. Another report showed that ambivalent beliefs about the practice were found among Nigerian mothers, where although over half of the respondents $(56.8 \%)$ perceived FGM as not being beneficial, yet $44.2 \%$ of the participants supported FGM [28]. Another study in Nigeria also stated that educated mothers were found to be less likely to favor the cutting of their daughters [29].

Consequently, much work and education are needed as an integral strategy to reduce FGM. Educational programs directed towards the public can play a major role in changing individual and social views. It is claimed that, basic education is a key method for eradicating FGM, and that the topic should be integrated into curricula and teacher training [30]. Records shows that, girls and women with no education are significantly more likely to be in favor of the existence of FGMfor example, in Kenya, approximately $38 \%$ of women and girls with no education supported the continuation of the practice, in comparison to approximately $6 \%$ of women and girls with secondary or higher education [31] Furthermore, as FGM is a sociocultural issue, it is essential that social changes take place in order to change the perspective of the society as whole, which thereby changes behaviors and ends the practice [30]. As a result, strategies should take an approach which targets the whole society, and not just women and girls just, or only those in school [30]. In regards to the legal regulations against FGM, it was proved that alone are inadequate, and that where these are accompanied by culturally-sensitive activities that educate and raise awareness, reductions in the prevalence of FGM have occurred [30].

According to the Social Convention Theory, the social norm is a social rule of behavior that all community members follow based on the expectations that others will follow [32]. When the Social Convention Theory is applied to FGM, an initial premise is that, parents tend to love their daughters and ultimately want to do the best for them [33]. At this point, the convention theory helps us understand why mothers let their beloved daughters go through this painful procedure, as well as reasons for their resistance to change [34]. The theory states that, the families' decision-making process is an interdependent process where a choice made by a family is affected by others and, in turn, it affects the choice made by other families [33-35]. In societies where FGM is a criterion for marriage, nearly all girls are circumcised for an appropriate wedding and to be publicly accepted and respected. In addition, since the possibility of circumcised girls getting married is high, the families' expectation to benefit from dowry is not as such negligible. On the other hand, if a girl does not get circumcised, she will face different problems. Apart from failing to get married, the girl will be treated as a social outcast. Under these challenging conditions, parents believed that FGM is the best way for their daughters to ensure them a good prospect. Similarly, the girls themselves would be indulged to welcome this painful fate of life to get accepted and be marriageable. Another challenging factor is peer pressure, which might act as an independent source for maintaining FGM. According to the Social Convention Theory, the challenge is, thus, to induce all families within the community group and change the equilibrium state of cutting to not cutting [36]. Doubtless that, the convection only works when a significant number of families within a community make a collective and coordinated choice to abandon the practice, and move together at the same time.

Consequently, to achieve FGM abandonment using Social Convention Theory, an entire community need not be persuaded; rather what is required is a motivated critical mass of people to collectively decide that they are willing to abandon the practice. This critical mass (particularly the young population) need to persuade others to commit to the idea until there are enough to act together to make a public commitment to abandon FGM [26]. Additionally, to reduce FGM, strategies must involve stakeholders at different levels (local and global) and from different sectors (health, education \& justice) and further target all within the society (individuals, communities, local leaders \& governments) [32]. Within a multi-sectoral approach, education is critical, as it can play a significant role in changing individual and societal views on FGM, and challenge social and gender norms. At individual level, education provides access to information, allows informed decision-making and empowers individuals to make their own independent choices. Schools and education programs offer an environment for teaching, learning and support, where knowledge and skills can help an individual address FGM. Schools and government play an important role in ensuring implementation of targeted educational programs, including teacher-training and curriculum development, which address FGM and related issues.

Policies that promote gender equality in education also lay a foundation for empowering women and girls, in addition to their 
decision-making capabilities and self-sufficiency. Community-based and public education can also contribute to breaking the silence on FGM, raising awareness, allowing for open discussion and addressing stigma and potential ostracization (for those that do not undergo FGM). Involving family members, traditional leaders, local authorities and the broader community in such initiatives is equally important in changing social attitudes and norms, and ensures that the underlying drivers are addressed in appropriate ways. Additionally, such initiatives are essential in reaching girls who are out-of-school, thus have no access to traditional school-based education. However, it is vital that strategies are community-led, as this ensures that programs are participatory and take into consideration different issues and solutions [32].

\section{Significance of the study}

WHO and UNICEF reported that, more than three million girls have been estimated to be at risk for FGM annually in Africa. In addition, over 125 million girls and women alive today have been subjected to cutting in 29 countries in Africa and the Middle East, where FGM is concentrated. The UNICEF stated that, Egypt had the highest (27.2 million) number of women and girls who went through FGM procedures. Although a variety of worldwide approaches have been undertaken to encourage rejection of FGM, yet few have been systematically evaluated to provide empirical evidence of whether they are effective in changing attitudes and behavior, either intended or actual $[3,37,38]$. However, there is some quantitative data on the impact of formal educational program on individual attitudes and beliefs towards the practice, but there is still a significant gap in research to determine whether popular educational campaigns and other programmatic efforts, which inform communities about the harmfulness of FGM have had success in lowering its rates or not. Additionally, some of these campaigns have not been rigorously evaluated. Thus, further research into the intersections of educational programs and FGM will be critical to proceed in order to improve efforts to combat this harmful practice and to bring effective practices to scale. Therefore, the current study was addressing the effectiveness of an educational program in exchanging knowledge, attitudes and practices of FGM among Egyptian mothers.

\section{For the Purpose of this Study, the Following Definitions are used}

\section{Knowledge}

"The capacity to acquire, retain and use information; a mixture of comprehension, experience, discernment and skill [39].

\section{Attitude}

"Inclinations to react a certain way to certain situations; to see and interpret events according to certain predispositions; or to organize opinions into coherent and interrelated structures [39].

\section{Practice}

"The application of rules and knowledge that leads to action [39].

\section{Female genital mutilation (FGM)}

Comprises all procedures that involve partial or total removal of the external female genitalia, or other injury to the female genital organs for non-medical reasons. It is usually performed for girls between the ages of four and 10. It is also called female circumcision [3].

\section{Educational program}

It is a nursing intervention outlined as planning, implementing, and evaluating a coordinated set of activities which designed to enhance wellness or to prevent, reduce, or eliminate one or more health problems of a group or community [40].

\section{Culture}

The integrated pattern of human knowledge, belief, and behavior that depends upon the capacity for learning and transmitting knowledge to succeeding generations also, it is the customary beliefs, social forms, and material traits of a racial, religious, or social group shared by people in a place or time [41]. KASA Instrument Design based on Bennett's Change Model, this model has been adopted to study impact of the independent variables knowledge, attitudes, and practices on the dependent variable of implementing the educational program of exchanging information of FGM. This paper addresses 3 areas of participant's determinants: knowledge, attitudes, and practices in relation to FGM (Figure 1). Bennett's knowledge, attitude, skills and aspirations (KASA) change hierarchy model has been revised to study the Impact of implementation of the educational program [42]. (Independent variable) on exchanging knowledge, attitudes, and practices (Dependent variable). Knowledge and attitudes play an important role in guiding how we react to the behavior of other people. The way mothers are reacting to the cultural, traditions, religious and environmental pressures of practicing FGM to their daughters will be influenced by their knowledge and attitudes towards these practices (behavior). This link between knowledge, attitude and behavior is reflected in KAP Instrument Design based on Bennett's Change Model. In the current research, to evaluate the effectiveness of the educational program (outcome), the researcher prepared the program and assessed what are the knowledge did the participants have and what are their' attitudes, towards FGM practices? What are the determinants factors that made their girls children at high risk for FGM behaviors? As well, what are the desired behaviors to change the outcome which is decreasing incidents of FGM behaviors among Egyptian girls? [42].

\section{Research Hypotheses}

The current study examined the effectiveness of an educational program on exchanging knowledge, attitudes and practices of FGM targeting teachers of primary coeducation school to support or reject these four hypotheses:

- The educational program envisioned for mothers to increase and exchange their knowledge, attitudes and practices towards FGM.

- Mothers who will attend the educational program will show no difference in their knowledge, attitudes and practices as measured by the self-administered questionnaire.

- Mothers who will receive the program will show no difference

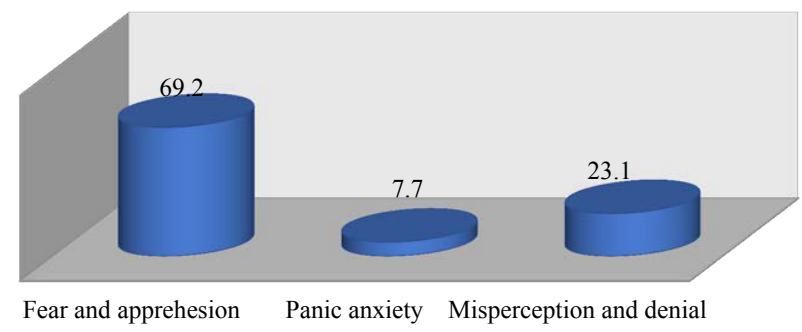

Figure 1: Respondents' psychological reactions during circumcision. 
Citation: Khalil Al, Orabi AM (2017) A Community-Based Intervention: Impact of an Educational Program in Exchanging Knowledge, Attitude, and Practices of Female Genital Mutilation (FGM). Health Care Current Reviews 5: 209. doi: 10.4172/2375-4273.1000209

in the ability to decide correctly to do or not do FGM to their girls as indicated by self-administered questionnaire.

- There is no correlation between mothers' knowledge, attitudes and practices of FGM and their sociodemographic characteristics.

\section{General objective}

It is investigating the effectiveness of an educational program in exchanging knowledge, attitudes and practices of (FGM).

\section{Specific objectives}

- Develop and prepare an educational program about FGM

- Evaluate the outcome of implementing the educational program through the following:

» Compare between participants' knowledge, attitudes and practices pre-and post-program.

» Correlates between participants' demographic background and their level of knowledge attitude and practices.

»Assess the effectiveness of the educational program in helping mothers to abandon the practice of FGM to their daughters.

\section{Participants and Methods}

\section{Design}

A quasi experimental research design (one group pre/postassessment) was used in the current study to achieve its objectives.

\section{Setting}

The study was conducted in Al Tonsi Primary school mixed education (male and female) which is located in Eastern area, and affiliated by Ministry of Art and Education, Cairo, Egypt

\section{Participants}

Total of 30 female teachers were contacted through a convenient sampling technique.

\section{Tools of the Study}

\section{The tool of the current study consisted of 4 parts as following}

First part concerned with participants' demographic characteristics such as age, educational level, address, marital status, husband's education, and job, family income and number of female children.

\section{Additionally, another 10 questions asking about their prac-} tices

These questions assessing if FGM is practiced in families/ households, whether they would subject their own daughters to the practice, and whether they are circumcised or not, if yes, they have to answer the following: at what age circumcision was performed to them, by whom, who took the decision of circumcision? What did they feel during and after the circumcision? Did they feel any advantage or benefit of being circumcised? If yes, what are the advantages/benefits? And did your family practice circumcision?

\section{The second section}

Is concerned with the participants' personal experience with female circumcision: it consisted of 2 main questions asking about their information about female circumcision? And what are their sources of that information?

\section{The third section is concerned with Knowledge about FGM}

The questionnaire was developed based on an extensive literature review. The questionnaire was structured along the response format ranging from yes ( 2 points) I don't know ( 1 point) and no (Zero point). It consisted of 14 questions asking about the participants' information regarding FGM. The questionnaire could be divided into 2 categories of basic information including: the synonyms of the word circumcision, is the practice is wide spread in Arabic world, the suitable age and that there are types of female circumcision. Female circumcision is religious commitment, tied to tradition, illegal practices, reduces sexual desire and increases the libido. In addition to 4 questions asking about the harmful effects of female circumcision including the physical, psychological and social problems and whether the governmental agencies are exerting an effort to combat the practice of female circumcision. This section measured the participant's level of awareness about FGM. The higher the score on the awareness scale, the higher the awareness and level of information. The scoring system used to categorize the knowledge level was as the following: a score $<9$ indicate poor level (0-33.3\%), a score of 9 to 18 indicates fair level (33.34-66.6\%) and a score $>19$ indicate good level (66.7-100\%).

\section{The $4^{\text {th }}$ section is concerned with Attitudes of the participants toward FGM}

This section consists of 2 parts as following:

First part: Consisted of 20 questions collected based on literature review. The scale was structured along the Likert-type response format. Scoring ranging from strongly agree (4 points) to strongly disagree (1 point). Of the twenty items in this section, six of them had a reversed scoring order; which indicated that the higher the score on the attitude scale, the less favorable the participants attitude to female circumcision. The scoring system used to categorize the attitude was as the following: a score $<27$ indicates negative attitude (0-33.3\%), a score of 27 to 53 indicates neutral attitude (33.34-66.6\%) and a score $>54$ indicates positive attitude (66.7-100\%).

The second part: Is a qualitative questionnaire which asked about whether the participants' have favourable attitudes towards continuation of FGM, reasons for encouraging continuation, suggestions for safety of the practice or discouraging its continuation and reasons for discontinuation of FGM.

\section{Validity and reliability of the tool}

The tool of the current study was tested for reliability and validity by the original developers. For the purpose of English language barriers observed in target group, the tool was translated into Arabic language and back translated into English language. Back translation aimed at verifying whether the translation covers all aspects of the original English version of the questionnaire or not. Then to ensure the face validity and reliability of the final translated Arabic version, the questionnaire was evaluated by a panel of experts who were selected on the basis of their qualifications and experience in nursing research and education. The tool was piloted and tested by 10 participants to check its clarity, feasibility, practicability and the time required for completing the questionnaire, and any difficulties that might be encountered by the participants in reading or understanding the questionnaire. The reliability of the questionnaires was assured through calculating 
Citation: Khalil Al, Orabi AM (2017) A Community-Based Intervention: Impact of an Educational Program in Exchanging Knowledge, Attitude, and Practices of Female Genital Mutilation (FGM). Health Care Current Reviews 5: 209. doi: 10.4172/2375-4273.1000209

Cronbach Alpha for knowledge and attitudes scales (0.702 and 0.922, respectively).

\section{Program Description and Procedure}

\section{Introduction}

The manager of the school was contacted by the researchers to receive an approval to conduct the study. Purpose of the study was explained for all teachers working in the school and an informed consent was taken from those who agreed to participate in the study. The program was conducted in 3 consecutive days starting from $22^{\text {nd }}$ to $24^{\text {th }}$ of August 2016, 10 participants each day, 4 sessions each day. A fixed outlines and schedule of the program was arranged and implemented to each group as following:

- 10-10.30 AM: The delivery of pretest information from the participants.

- 10.30 AM-12 PM: Implementing the educational program.

- 12 PM-12.30 PM: Conducting the posttest to the participants.

- 12.30 PM-13.30 PM Assessment of the participants' weight, height, blood pressure, breast self-examination awareness was implemented to all participants as a reward for their cooperation and participation in the program.

\section{Components of the Program}

\section{Theoretical background}

This part consisted of defining what is FGM? What are the terms and functions of FGM? What is its significance? What are the organs of external genitalia and the functions of each? What are the types of circumcision? And what are the complications of circumcision? What is the Religion opinion (Islamic and Christian) of circumcision? What are the cultural issues in FGM? What is the position of medical organizations in Egypt? And finally, what is the position of the Egyptian law?

\section{Method of instructions}

Various instructional methods were used to facilitate the introduction of information in form of:

- Lecture/PowerPoint presentation, showing pictures, group discussion

- Listening for feedback.

- Video showing about female genital system and its function.

\section{Data Management and Analysis Plan}

The data was coded and analyzed using SPSS version 20.0. Data was presented using descriptive statistics for discrete variables in the form of frequencies and percentages, and for interval and ratio variables in the form of means and standard deviations. A paired t test was used to analyze the total scores of the participants' responses on the pre-test and the post-test (i.e., before and after implementation of the educational program). Participants' sociodemographic and knowledge difference was analyzed using Chi Square test $\left(\chi^{2}\right)$. Pearson $r$ was used to test the correlation between parents' knowledge and sociodemographic variables. The significance level is pre-set at $\mathrm{p}<0.05$.

\section{Ethical Considerations}

An official approval from the manager of Al Tonsi Primary school mixed education was granted for data collection. The participants were informed about the purpose of the study, and that their participation is voluntary and they can withdraw from the study at any time. A written consent was obtained from all participants. Anonymity was ensured by using identification codes on the questionnaires that facilitated individual comparison of pre-and post-educational program responses.

\section{Results}

\section{Description of the respondents by their sociodemographic characteristics}

As regards the socio-demographic characteristics of the respondents, showed that, mean age was $36.93 \pm 8.42$ with a range of 25-50.0 years, mean family income was $30.033 .33 \pm 655.66$ with a range of $2000-4000$ pounds and mean number of daughters was $1.47 \pm 0.0 .73$ with a range of 0.0-3 daughters (Table 1). Majority of respondents had university education, grown up in urban areas and were married $(80.0 \%, 73.3 \%$ and $86.6 \%$, respectively). In relation to their husbands, $60.0 \%$ of them had university education and $80.0 \%$ of them were employees (Table 1 ).

\section{Description of the respondents by their personal experience with female genital circumcision}

Concerning the personal experience of the respondents, revealed that, $26.7 \%$ of the respondents had circumcised all their daughters and $13.3 \%$ of them had circumcised some of them. More than half (53.3\%) of the respondents have some information about female circumcision (Table 2). Their information had been retrieved from media and mothers, grandmothers and friends $(43.8 \%$ and $56.2 \%$, respectively). In the same perspective, $86.7 \%$ of the respondents' big families are performing circumcision for their daughters. Additionally, majority of the respondents (86.7\%) were circumcised, $77 \%$ of them were circumcised by traditional birth attendants (Daya). Moreover, the decision of circumcision for all circumcised respondents was taken by their mothers and grandmothers. Further, $23 \%$ of the circumcised respondents reported that, they felt benefits of being circumcised in terms of decreasing sexual desire (10.00.0\%) and maintaining chastiy

\begin{tabular}{|c|c|c|}
\hline Characteristic & Frequency $(n=30.0)$ & $\%$ \\
\hline \multirow{2}{*}{$\begin{array}{l}\text { Age in years } \\
25-34 \\
35-44 \\
45-50.0 \\
\text { Mean } \pm \text { SD. }\end{array}$} & $\begin{array}{c}14 \\
6 \\
10.0\end{array}$ & $\begin{array}{l}46.7 \\
20.0 \\
33.3\end{array}$ \\
\hline & \multicolumn{2}{|c|}{$36.93 \pm 8.42$} \\
\hline $\begin{array}{l}\text { Educational level } \\
\text { University } \\
\text { High institute }\end{array}$ & $\begin{array}{c}24 \\
6\end{array}$ & $\begin{array}{l}80.0 \\
20.0\end{array}$ \\
\hline $\begin{array}{l}\text { Grownup area } \\
\text { Rural } \\
\text { Urban }\end{array}$ & $\begin{array}{c}8 \\
22\end{array}$ & $\begin{array}{l}26.7 \\
73.3\end{array}$ \\
\hline $\begin{array}{l}\text { Marital status } \\
\text { Married } \\
\text { Divorced } \\
\text { Widow } \\
\end{array}$ & $\begin{array}{c}26 \\
2 \\
2 \\
\end{array}$ & $\begin{array}{c}86.6 \\
6.7 \\
6.7\end{array}$ \\
\hline \multirow{2}{*}{$\begin{array}{l}\text { Family income in pounds } \\
20.00 .00 .0-250.00 .0 \\
30.00 .00 .0-350.00 .0 \\
40.00 .00 .0 \\
\text { Mean } \pm \text { SD. }\end{array}$} & $\begin{array}{c}10.0 \\
14 \\
6\end{array}$ & $\begin{array}{l}33.3 \\
46.7 \\
20.0\end{array}$ \\
\hline & \multicolumn{2}{|c|}{$30.033 .33 \pm 655.66$} \\
\hline \multirow{2}{*}{$\begin{array}{l}\text { Number of daughters } \\
0.0-1 \\
2-3 \\
\text { Mean } \pm S D\end{array}$} & $\begin{array}{l}16 \\
14\end{array}$ & $\begin{array}{l}53.3 \\
46.7\end{array}$ \\
\hline & \multicolumn{2}{|c|}{$1.47 \pm 0.0 .73$} \\
\hline
\end{tabular}

Table 1: Respondents' socio-demographic characteristics. 
Citation: Khalil Al, Orabi AM (2017) A Community-Based Intervention: Impact of an Educational Program in Exchanging Knowledge, Attitude, and Practices of Female Genital Mutilation (FGM). Health Care Current Reviews 5: 209. doi: 10.4172/2375-4273.1000209

Page 6 of 11

\begin{tabular}{|c|c|c|}
\hline Item & Frequency & $\%$ \\
\hline $\begin{array}{l}\text { Did you circumcise your daughter/s? }(n=30.0) \\
\text { Yes } \\
\text { No } \\
\text { Some } \\
\text { No daughters }\end{array}$ & $\begin{array}{c}8 \\
16 \\
4 \\
2\end{array}$ & $\begin{array}{l}26.7 \\
53.3 \\
13.3 \\
6.7\end{array}$ \\
\hline $\begin{array}{l}\text { Do you have any information about female circumcision? }(n=\mathbf{3 0 . 0}) \\
\text { Yes } \\
\text { No }\end{array}$ & $\begin{array}{l}16 \\
14\end{array}$ & $\begin{array}{l}53.3 \\
46.7 \\
\end{array}$ \\
\hline $\begin{array}{l}\text { What is your source of information? }(\mathbf{n}=16) \\
\text { Media } \\
\text { Mother and grandmother } \\
\text { Friends }\end{array}$ & $\begin{array}{l}7 \\
6 \\
3\end{array}$ & $\begin{array}{l}43.8 \\
37.4 \\
18.8\end{array}$ \\
\hline $\begin{array}{l}\text { Did your big family practice circumcision? }(n=30.0) \\
\text { Yes } \\
\text { No }\end{array}$ & $\begin{array}{c}26 \\
4\end{array}$ & $\begin{array}{l}86.7 \\
13.3 \\
\end{array}$ \\
\hline $\begin{array}{l}\text { Are you circumcised/? }(\mathbf{n}=\mathbf{3 0 . 0}) \\
\text { Yes } \\
\text { No }\end{array}$ & $\begin{array}{c}26 \\
4\end{array}$ & $\begin{array}{l}86.7 \\
13.3 \\
\end{array}$ \\
\hline $\begin{array}{l}\text { What was your age when you have been circumcised? }(\mathbf{n}=\mathbf{2 6}) \\
9-10.0 \\
11-12\end{array}$ & $\begin{array}{l}12 \\
14\end{array}$ & $\begin{array}{l}46.2 \\
53.8\end{array}$ \\
\hline $\begin{array}{l}\text { By whom circumcision was performed to you? }(\mathbf{n}=\mathbf{2 6}) \\
\text { Traditional birth attendant } \\
\text { Nurse }\end{array}$ & $\begin{array}{c}20.0 \\
6\end{array}$ & $\begin{array}{l}77 \\
23\end{array}$ \\
\hline $\begin{array}{l}\text { Who took the decision of your circumcision? }(\mathbf{n}=\mathbf{2 6}) \\
\text { Mother } \\
\text { Mother and grandmother }\end{array}$ & $\begin{array}{l}14 \\
12\end{array}$ & $\begin{array}{l}53.8 \\
46.2\end{array}$ \\
\hline $\begin{array}{l}\text { Did you feel any advantage or benefit of being circumcised? }(n=26) \\
\text { Yes } \\
\text { No }\end{array}$ & $\begin{array}{c}6 \\
20.0\end{array}$ & $\begin{array}{l}23 \\
77\end{array}$ \\
\hline
\end{tabular}

Table 2: Respondents' personal experience with female circumcision.

(50.0\%). In the same context, described that, $69.2 \%$ of the respondents felt fear and apprehension during circumcision (Figure 1). Additionally, described that; the common reported psychological reactions after circumcision were sadness, embarrassment and misperception $(27.3 \%$, $25.2 \%$ and $18.3 \%$, respectively) (Figure 2 ).

\section{Description of the Respondents by their Knowledge and Attitudes toward Female Circumcision in the Pre-test and the Post-Test}

Concerning knowledge of the respondents about female circumcision, the mean total score in the pre-test was $11.7 \pm 2.0 .0$ out of 28 indicating fair level as compared to $27.4 \pm 1.3$ which indicates good level in the post-test with a statistical significant difference $(\mathrm{P}<0.0 .0 .00 .00 .01)$. Additionally, the mean total score of respondents' attitude toward female circumcision in the pre-test was $43.9 \pm 6.8$ out of 80.0 indicating neutral attitude as compared to $26.5 \pm 1.6$ which indicates negative attitude in the post-test with a statistical significant difference $(\mathrm{P}<0.0 .0 .00 .00 .01)$ (Figure 3$)$. Revealed that the respondents agreed upon female circumcision reduces promiscuity, for religious reasons it should be encouraged and it protects against sexual deviation such as lesbianism $(66.7 \%, 53.3 \%$ and $53.3 \%$, respectively) in the pre-test as compared to $0.0 .0 .0 \%$ in the post-test interventions (Tables 3 and 4 ).

\section{Description of the Respondents by their Reaction to- ward Future Practice of Female Circumcision}

Considering the reaction of the respondents toward future practice of female circumcision, $20.0 \%$ of them planned to circumcise their daughters in the pre-test as compared to $0.0 .0 .0 \%$ in the post-test. Moreover, $20.0 \%$ of the respondents reported that female circumcision has health benefits in the pre-test as compared to $6.7 \%$ in the post-test. As regard to the reported benefits in the pre-test, majority $(83.3 \%)$ of

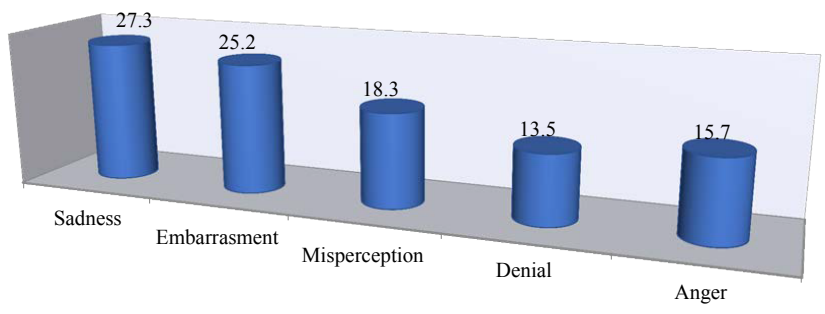

Figure 2: Respondents' psychological reactions after circumcision.

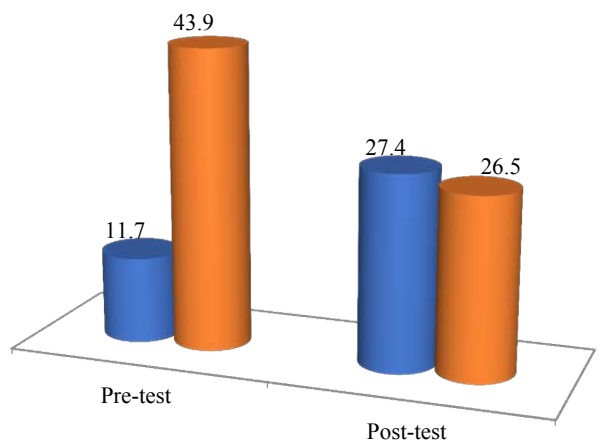

- Knowledge - Attitude

Figure 3: Respondents' mean total knowledge and attitude scores in the pretest and the post-test.

the respondents reported maintaining Chasity and purity while half of the respondents $50.0 \%$ equally reported the benefits of preventing enlargement of genital organs, decreasing sexual desire, and decreasing the occurrence of infection (Figure 4). While, all respondents $(10.00 .0 .0 .0 \%)$ reported benefit in the post-test was treating genital 
Citation: Khalil AI, Orabi AM (2017) A Community-Based Intervention: Impact of an Educational Program in Exchanging Knowledge, Attitude, and Practices of Female Genital Mutilation (FGM). Health Care Current Reviews 5: 209. doi: 10.4172/2375-4273.1000209

Page 7 of 11

\begin{tabular}{|c|c|c|c|c|c|c|c|}
\hline \multirow{2}{*}{ No. } & \multirow{2}{*}{ Item } & \multicolumn{2}{|c|}{$\begin{array}{c}\text { Yes } \\
2\end{array}$} & \multicolumn{2}{|c|}{$\begin{array}{l}\text { Do not know } \\
\quad 1\end{array}$} & \multicolumn{2}{|c|}{$\begin{array}{l}\text { No } \\
0.0\end{array}$} \\
\hline & & $\begin{array}{l}\text { Pre-test } \\
\%\end{array}$ & $\begin{array}{c}\text { Post-test } \\
\%\end{array}$ & $\begin{array}{l}\text { Pre-test } \\
\%\end{array}$ & $\begin{array}{c}\text { Post-test } \\
\%\end{array}$ & $\begin{array}{l}\text { Pre-test } \\
\%\end{array}$ & $\begin{array}{c}\text { Post-test } \\
\%\end{array}$ \\
\hline 1 & $\begin{array}{l}\text { From synonyms for the word circumcision "purity, genital mutilation, or female genital } \\
\text { mutilation". }\end{array}$ & 0.0 & 96.7 & 93.3 & 3.3 & 6.7 & 0.0 \\
\hline 2 & Practice of female circumcision is widespread in Arabic world. & 0.0 & 96.7 & 20.0 & 3.3 & 80.0 & 0.0 \\
\hline 3 & Female circumcision is performed before the age of puberty. & 60.0 & 10.00 .0 & 40.0 & 0.0 & 0.0 & 0.0 \\
\hline 4 & There are types of female circumcision. & 0.0 & 96.7 & 93.3 & 3.3 & 6.7 & 0.0 \\
\hline 5 & All types of female circumcision are harmful. & 0.0 & 93.3 & 86.7 & 6.7 & 13.3 & 0.0 \\
\hline 6 & Female circumcision has health complications such as bleeding and bacterial infection. & 0.0 & 96.7 & 66.7 & 3.3 & 33.3 & 0.0 \\
\hline 7 & Female circumcision causes psychological problems. & 0.0 & 93.3 & 66.7 & 6.7 & 33.3 & 0.0 \\
\hline 8 & Female circumcision causes social problems. & 0.0 & 86.6 & 73.3 & 6.7 & 26.7 & 6.7 \\
\hline 9 & Female circumcision is not a religious commitment. & 3.3 & 10.00 .0 & 60.0 & 0.0 & 36.7 & 0.0 \\
\hline 10.0 & Female circumcision is usually tied to tradition. & 73.3 & 10.00 .0 & 26.7 & 0.0 & 0.0 & 0.0 \\
\hline 11 & Practice of female circumcision is illegal. & 0.0 & 93.3 & 80.0 & 0.0 & 20.0 & 6.7 \\
\hline 12 & Female circumcision does not reduce sexual desire. & 0.0 & 10.00 .0 & 53.3 & 0.0 & 46.7 & 0.0 \\
\hline 13 & Lack of female circumcision does not increase the libido. & 0.0 & 96.7 & 53.3 & 3.3 & 46.7 & 0.0 \\
\hline 14 & Governmental agencies are exerting an effort to combat the practice of female circumcision. & 6.6 & 10.00 .0 & 66.7 & 0.0 & 26.7 & 0.0 \\
\hline
\end{tabular}

Table 3: Respondents' knowledge about female genital circumcision in the pre-test and post-test.

\begin{tabular}{|c|c|c|c|c|c|c|c|c|c|}
\hline \multirow{2}{*}{ No. } & \multirow[t]{2}{*}{ Item } & \multicolumn{2}{|c|}{$\begin{array}{l}\text { Strongly agree } \\
4\end{array}$} & \multicolumn{2}{|c|}{$\begin{array}{l}\text { Agree } \\
3\end{array}$} & \multicolumn{2}{|c|}{$\begin{array}{l}\text { Dis-agree } \\
\quad 2\end{array}$} & \multicolumn{2}{|c|}{$\begin{array}{l}\text { Strongly Disagree } \\
1\end{array}$} \\
\hline & & $\begin{array}{c}\text { Pre-test } \\
\%\end{array}$ & $\begin{array}{c}\text { Post-test } \\
\%\end{array}$ & $\begin{array}{c}\text { Pre-test } \\
\%\end{array}$ & $\begin{array}{c}\text { Post-test } \\
\%\end{array}$ & $\begin{array}{c}\text { Pre-test } \\
\%\end{array}$ & $\begin{array}{c}\text { Post-test } \\
\%\end{array}$ & $\begin{array}{l}\text { Pre-test } \\
\%\end{array}$ & $\begin{array}{c}\text { Post-test } \\
\%\end{array}$ \\
\hline 1 & Female circumcision makes the external genitalia more attractive. & 10.0 & 0.0 & 33.4 & 10.0 & 53.3 & 33.3 & 3.3 & 56.7 \\
\hline 2 & I feel that the practice of female circumcision should continue in our society. & 0.0 & 0.0 & 40.0 & 0.0 & 60.0 & 20.0 & 0.0 & 80.0 \\
\hline 3 & Female circumcision reduces promiscuity. & 0.0 & 0.0 & 66.7 & 0.0 & 33.3 & 40.0 & 0.0 & 60.0 \\
\hline 4 & Non- circumcised woman is not a female. & 0.0 & 0.0 & 13.3 & 0.0 & 80.0 & 40.0 & 6.7 & 60.0 \\
\hline *5 & Female circumcision is harmful and is considered from the inhumane practices. & 6.7 & 93.3 & 53.3 & 6.7 & 40.0 & 0.0 & 0.0 & 0.0 \\
\hline *6 & Female circumcision is one of the acts of violence against woman. & 6.7 & 86.7 & 60.0 & 13.3 & 33.3 & 0.0 & 0.0 & 0.0 \\
\hline *7 & $\begin{array}{l}\text { The government should enact a law making female circumcision a criminal } \\
\text { and punishable offense. }\end{array}$ & 6.6 & 66.7 & 46.7 & 33.3 & 46.7 & 0.0 & 0.0 & 0.0 \\
\hline *8 & Practice of female circumcision should not be encouraged in our society. & 6.6 & 80.0 & 46.7 & 20.0 & 46.7 & 0.0 & 0.0 & 0.0 \\
\hline 9 & I believe that female circumcision promotes chastity. & 0.0 & 0.0 & 53.3 & 0.0 & 46.7 & 33.3 & 0.0 & 66.7 \\
\hline 10.0 & Practice of female circumcision is an old tradition that should be preserved. & 6.6 & 0.0 & 46.7 & 0.0 & 46.7 & 6.7 & 0.0 & 93.3 \\
\hline 11 & For religious reasons, female circumcision should be encouraged. & 0.0 & 0.0 & 53.3 & 0.0 & 40.0 & 40.0 & 6.7 & 60.0 \\
\hline 12 & Female circumcision protects against sexual deviation such as lesbianism. & 0.0 & 0.0 & 53.3 & 0.0 & 46.7 & 46.7 & 0.0 & 53.3 \\
\hline 13 & Female circumcision is necessary to ensure the stability of marital life. & 0.0 & 0.0 & 46.7 & 0.0 & 53.3 & 26.7 & 0.0 & 73.3 \\
\hline 14 & Non-circumcised woman is not chaste and pure. & 0.0 & 0.0 & 6.7 & 0.0 & 93.3 & 13.3 & 0.0 & 86.7 \\
\hline *15 & $\begin{array}{l}\text { Practice of female circumcision should be refrained, taking into account its } \\
\text { negative consequences. }\end{array}$ & 0.0 & 73.3 & 46.7 & 26.7 & 53.3 & 0.0 & 0.0 & 0.0 \\
\hline 16 & $\begin{array}{l}\text { If I have the opportunity to choose between circumcision or not, I will choose } \\
\text { circumcision. }\end{array}$ & 0.0 & 0.0 & 0.0 & 0.0 & 66.7 & 20.0 & 33.3 & 80.0 \\
\hline 17 & Female circumcision is an obligation and one of the rituals of Islam. & 0.0 & 0.0 & 0.0 & 0.0 & 66.7 & 10.0 & 33.3 & 90.0 \\
\hline 18 & Circumcision is an eligible right in Islam for male and female. & 0.0 & 0.0 & 0.0 & 0.0 & 6.7 & 10.00 .0 & 93.3 & 0.0 \\
\hline 19 & Female circumcision is preferable but not an obligation in Islam. & 0.0 & 0.0 & 0.0 & 0.0 & 26.7 & 36.7 & 73.3 & 63.3 \\
\hline *20 & Men prefer a non-circumcised female. & 40.0 & 53.3 & 43.3 & 33.3 & 16.7 & 13.3 & 0.0 & 0.0 \\
\hline
\end{tabular}

Table 4: Respondents' attitude toward female genital circumcision in the pre-test and post-test.

disease or clitoris enlargement. Further, $53.3 \%$ of respondents encouraged the continuity of female circumcision in the pre-test as compared to $6.7 \%$ in the post-test. Moreover, the respondents suggested for safe practice of female circumcision, $(62.5 \%)$ it should be performed in a hospital, (37.5\%) a well-equipped clinic, (50.0\%) by doctor or nurse and $10.00 .0 \%$ reported to be before puberty in the pre-test intervention as compared to $50.0 \%, 10.00 .0 \%, 10.00 .0 \%$ and $10.00 .0 \%$, respectively in the post-test program (Table 5).

The reported reasons for encouraging continuation of female circumcision in the pre-test were decreasing sexual desire $(62.5 \%)$, preventing promiscuity and sexual deviations (68.8\%), and ensuring chasity

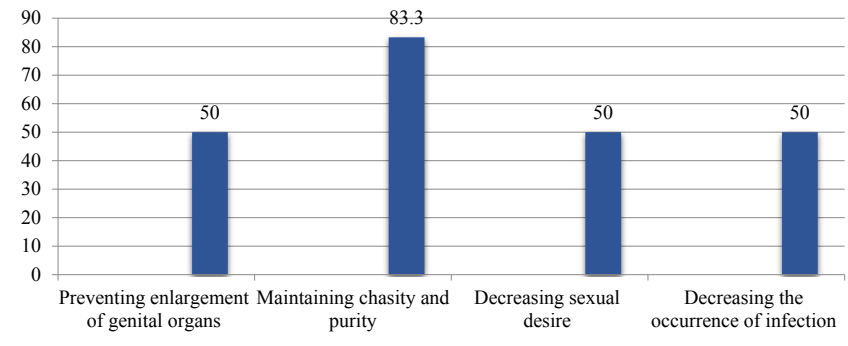

Figure 4: Respondents' reported health benefits of female circumcision in the pre-test. 
Citation: Khalil Al, Orabi AM (2017) A Community-Based Intervention: Impact of an Educational Program in Exchanging Knowledge, Attitude, and Practices of Female Genital Mutilation (FGM). Health Care Current Reviews 5: 209. doi: 10.4172/2375-4273.1000209

Page 8 of 11

\begin{tabular}{|c|c|c|c|c|}
\hline \multirow{2}{*}{ Item } & \multicolumn{2}{|c|}{ Pre-test } & \multicolumn{2}{|c|}{ Post-test } \\
\hline & Frequency & $\%$ & Frequency & $\%$ \\
\hline \multirow{2}{*}{$\begin{array}{l}\text { Are you going to circumcise your daughter in the future? } \\
\text { - Yes } \\
\text { - No } \\
\text { - N.A (Already circumcised or had no daughters) }\end{array}$} & $(n=30.0)$ & & $(n=30.0)$ & \\
\hline & $\begin{array}{c}6 \\
14 \\
10.0\end{array}$ & $\begin{array}{l}20.0 \\
46.7 \\
33.3\end{array}$ & $\begin{array}{l}0.0 \\
20.0 \\
10.0\end{array}$ & $\begin{array}{c}0.0 \\
66.7 \\
33.3\end{array}$ \\
\hline \multirow{2}{*}{$\begin{array}{l}\text { Does female circumcision have health benefits? } \\
\text { - Yes } \\
\text { - No }\end{array}$} & $(n=30.0)$ & & $(n=30.0)$ & \\
\hline & $\begin{array}{c}6 \\
24\end{array}$ & $\begin{array}{l}20.0 \\
80.0\end{array}$ & $\begin{array}{c}2 \\
28\end{array}$ & $\begin{array}{c}6.7 \\
93.3\end{array}$ \\
\hline \multirow{2}{*}{$\begin{array}{l}\text { Do you encourage the continuity of female circumcision? } \\
\text { - Yes } \\
\text { - No }\end{array}$} & $(n=30.0)$ & & $(n=30.0)$ & \\
\hline & $\begin{array}{l}16 \\
14\end{array}$ & $\begin{array}{l}53.3 \\
46.7\end{array}$ & $\begin{array}{c}2 \\
28\end{array}$ & $\begin{array}{c}6.7 \\
93.3\end{array}$ \\
\hline $\begin{array}{l}\text { *What would you suggest for safe female circumcision? } \\
\text { - Done in a hospital } \\
\text { - Done in a well-equipped clinic } \\
\text { - Using sterile equipment }\end{array}$ & $\begin{array}{c}10.0 \\
6 \\
14\end{array}$ & $\begin{array}{l}62.5 \\
37.5\end{array}$ & $\begin{array}{l}1 \\
2 \\
1\end{array}$ & $\begin{array}{l}50.0 \\
10.00 .0 \\
50.0\end{array}$ \\
\hline \multirow{2}{*}{$\begin{array}{l}\text { What is the suitable age to perform female circumcision? } \\
\text { - Before puberty }\end{array}$} & $(n=16)$ & & $(n=2)$ & \\
\hline & 16 & 10.00 .0 & 2 & 10.00 .0 \\
\hline $\begin{array}{l}\text { *Why? } \\
\text { - To have less pain } \\
\text { - To be easily forgotten by the girl } \\
\text { - To have less bleeding }\end{array}$ & $\begin{array}{c}14 \\
12 \\
0.0 .0 .0\end{array}$ & $\begin{array}{c}87.5 \\
75 \\
0.0 .0 .0\end{array}$ & $\begin{array}{c}2 \\
0.0 .0 .0 \\
1\end{array}$ & $\begin{array}{c}10.00 .0 \\
0.0 .0 .0 \\
50.0\end{array}$ \\
\hline \multirow{2}{*}{$\begin{array}{l}\text { Who should perform female circumcision? } \\
\text { - Doctor } \\
\text { - Nurse } \\
\text { - Doctor and nurse }\end{array}$} & $(n=16)$ & & $(n=2)$ & \\
\hline & $\begin{array}{l}6 \\
2 \\
8\end{array}$ & $\begin{array}{l}37.5 \\
12.5 \\
50.0\end{array}$ & $\begin{array}{l}0.0 .0 .0 \\
0.0 .0 .0 \\
2\end{array}$ & $\begin{array}{l}0.0 .0 .0 \\
0.0 .0 .0 \\
10.00 .0\end{array}$ \\
\hline
\end{tabular}

${ }^{*}$ Total is not inclusive

Table 5: Respondents' reaction toward future practice of safe female circumcision.

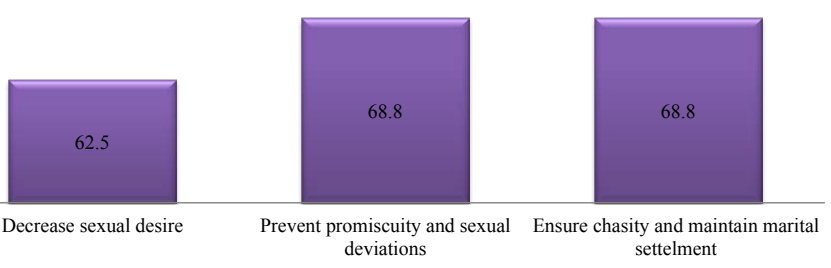

*Total is not inclusive

Figure 5: Respondents' reported reasons for encouraging continuation of female circumcision in the pre-test.

and marital settlement (68.8\%). While, (10.00.0\%) of the respondents reported that the reason for encouraging continuation of female circumcision in the post-test was treating female genital enlargement (Figure 5). However, the reported reasons for discouraging continuation of female circumcision in the pre-test, majority $(71.4 \%)$ of the respondents equally reported, it causes pain and fear and may cause infection, bleeding and death while, (57\%) stated it has no benefits as compared to $42.9 \%$, $35.7 \%$ and $42.9 \%$ in the post-test respectively (Tables 6 and 7). Reveals that, age of the respondents was significantly correlated with their total attitude score in the pretest $(\mathrm{P}=0.002)$ (Table 8$)$. Further, number of daughters was significantly correlated with total attitude score in the pretest and the posttest $(\mathrm{P}=0.03$ and $\mathrm{P}=0.01)$. Additionally, results showed that, predictors for total knowledge and attitude scores in the pretest and posttest were grown up area $(\mathrm{P}=0.002)$ and marital status $(\mathrm{P}=0.04$ and 0.01$)$ (Table 9). Moreover, willingness to circumcise the respondents' daughters in the pretest was significantly associated with their grownup area, educational level $(\mathrm{P}<0.001)$ and marital status $(\mathrm{P}=0.001)$.

\section{Discussion}

The current study examined knowledge, attitudes and practices of female teachers in a primary school in Cairo, Egypt, before and after the conduction of an educational program regarding FGM. Four hypotheses

\begin{tabular}{|c|l|c|c|}
\hline No. & \multicolumn{1}{|c|}{ Item } & $\begin{array}{c}\text { Frequency } \\
(\mathbf{n = 1 4 )}\end{array}$ & $\%$ \\
\hline 1 & Causes pain and fear & 10.0 & 71.4 \\
\hline 2 & Has no benefits & 8 & 57 \\
\hline 3 & May cause infection, bleeding or death & 10.0 & 71.4 \\
\hline 4 & Has negative effects on sexual relation & 6 & 42.9 \\
\hline
\end{tabular}

*Total is not inclusive.

Table 6: Respondents' reported reasons for discouraging female circumcision in the pre-test.

\begin{tabular}{|c|l|c|c|}
\hline No. & \multicolumn{1}{|c|}{ Item } & $\begin{array}{c}\text { Frequency } \\
(\mathbf{n = 2 8 )}\end{array}$ & $\%$ \\
\hline 1 & Causes pain and fear & 12 & 42.9 \\
\hline 2 & Has no benefits & 10.0 & 35.7 \\
\hline 3 & May cause infection, bleeding or death & 12 & 42.9 \\
\hline 4 & Done by unqualified personnel & 10.0 & 35.7 \\
\hline 5 & Most girls do not need to be circumcised & 14 & 50.0 \\
\hline 6 & $\begin{array}{l}\text { Chasity is the product of growing up and good } \\
\text { manners not from circumcision }\end{array}$ & 16 & 57 \\
\hline 7 & Sexual desire starts from the brain & 11 & 39.3 \\
\hline 8 & It is not from Islamic rituals & 13 & 46.4 \\
\hline 9 & Causes psychological or social problems & 9 & 32 \\
\hline
\end{tabular}

*Total is not inclusive

Table 7: Respondents' reported reasons for discouraging female circumcision in the post-test.

were formulated for the current study. Findings revealed that, the first one had been accepted while the second and third hypotheses had been rejected, as the educational program promoted exchange of the respondents' knowledge, attitudes and practices towards FGM, as well as their ability to decide whether to circumcise their daughters or not. In this perspective, the respondents' knowledge and attitudes towards FGM practice had been improved after the implementation of the program from a fair level to good and from a neutral attitude to a negative one. This implies that, the educational program was effective 
Citation: Khalil Al, Orabi AM (2017) A Community-Based Intervention: Impact of an Educational Program in Exchanging Knowledge, Attitude, and Practices of Female Genital Mutilation (FGM). Health Care Current Reviews 5: 209. doi: 10.4172/2375-4273.1000209

Page 9 of 11

\begin{tabular}{|c|c|c|c|c|c|c|c|c|}
\hline \multirow{3}{*}{ Item } & \multicolumn{4}{|c|}{ Total knowledge score } & \multicolumn{4}{|c|}{ Total attitude score } \\
\hline & \multicolumn{2}{|c|}{ Pre-test } & \multicolumn{2}{|c|}{ Post-test } & \multicolumn{2}{|c|}{ Pre-test } & \multicolumn{2}{|c|}{ Post-test } \\
\hline & $\mathbf{R}$ & $\mathbf{P}$ & $\mathbf{R}$ & $\mathbf{P}$ & $\mathbf{R}$ & $\mathbf{P}$ & $\mathbf{R}$ & $\mathbf{P}$ \\
\hline Age in years & -0.17 & 0.37 & -0.27 & 0.15 & 0.53 & ${ }^{*} 0.002$ & 0.04 & 0.84 \\
\hline Family income & -0.13 & 0.51 & -0.12 & 0.53 & 0.25 & 0.19 & -0.18 & 0.34 \\
\hline Number of daughters & 0.26 & 0.17 & -0.34 & 0.07 & 0.40 & ${ }^{*} 0.03$ & 0.46 & ${ }^{*} 0.01$ \\
\hline
\end{tabular}

Table 8: Correlation between respondents' socio-demographic characteristics and their knowledge and attitude scores in the pre-test and post-test.

\begin{tabular}{|l|c|c|c|c|c|c|c|}
\hline \multirow{2}{*}{\multicolumn{1}{|c|}{ Item }} & \multicolumn{4}{|c|}{ Total knowledge score } & \multicolumn{2}{c|}{ Total attitude score } \\
\cline { 2 - 7 } & B & SE & t & P & B & SE \\
\hline Marital status & 1.29 & 0.62 & 2.08 & 0.04 & 5.47 & 2.04 \\
\hline Grownup area & 1.86 & 0.52 & 3.54 & 0.002 & 2.68 \\
\hline
\end{tabular}

B: Coefficient of Determination; SE: Standard Error

Table 9: Predictors for respondents' knowledge and attitudes toward FGM in the pre-test and post-test.

in changing attitudes and replacing misperceptions of the study's respondents with correct information. These findings correspond with those of a previous Ethiopian study, as community education promoted attitude change towards FGM practice [43]. However, pretest scores revealed ambivalence in the respondents' beliefs, as although they had a fair knowledge about FGM, they had a neutral attitude towards it simultaneously. The explanation for this contradiction lies within the mass media, which helped in raising awareness regarding the risks of the practice. Despite that, there is still a need for ongoing campaigns, offering direct contact with the mothers to correct misconceptions, answer questions and alleviate worries. In the same line, Ahanonu and Victor [27] found that, over half of the respondents viewed FGM as harmful; nonetheless, they thought that it prevents sexual promiscuity and contributes to faithfulness to the husband. Moreover, Abo and Gbadebo [28], that, Egyptian medical students had a modest knowledge about FGM and a neutral attitude towards it as well. In contrast, Abolfotouh et al. reported that, most of school students in Ethiopia had a negative attitude towards FGM [26].

Concerning the past and future practices of FGM among the study respondents, more than half of them were aware of the practice and most of their extended families were performing. Additionally, majority of them had experienced it themselves and nearly one half of their daughters. It is important to mention that, the circumcision decision for all respondents had been taken by their mothers and grandmothers. Additionally, more than half of the respondents retrieved their information about FGM from unscientific sources-such as mothers, grandmothers and friends. In consistence, a descriptive cross-sectional study that assessed the perception of pregnant women in Nigeria to FGM showed that, the majority of the participants were aware of the practice. Furthermore, of those aware of FGM, one third had experienced it themselves [44]. Regarding future FGM practice, half of the study's respondents encouraged its continuity in the pretest. Further, nearly one quarter of them planned to circumcise their daughters to maintain purity, chastity and to achieve marital settlements. In addition, two thirds of them believed that FGM reduces promiscuity in correspondence with a previous Nigerian study, which showed that mothers viewed FGM as a mean to prevent sexual promiscuity [45]. However, an improvement had been noted in the posttest, as none of them intended to circumcise their daughters. In addition, less than one tenth of them considered FGM as beneficial and can be continued only in case of presence of genital disease or enlargement. In the same line, a descriptive study conducted in Somalia showed that, more than half of the study's participants discouraged the continuation of FGM [36]. In contrast, Afifi and Bothmer [45] reported that, three quarters of Egyptian women intended to continue FGM practice. Furthermore, one fifth of the midwives in Eastern Sudan intended to circumcise their daughters due to easy labor, tradition and marital settlements [46,47].

Consistent with FGM consequences, pain and fear were mainly experienced by the participants, which were reported as justifications for discouraging the continuation of FGM in the pretest, in addition to the liability of infection, bleeding and death; as the majority of them had unsafe procedures performed by traditional birth attendants (Daya), who are uneducated and untrained personnel. In the posttest, most of them discouraged the continuation of FGM practice. This is mainly due to, the implementations done to the educational program, which clarified that chastity is mainly related to growing up, that sexual desire, physiologically, starts from the brain, that FGM is not an Islamic ritual, and most girls do not need to be circumcised. The interpretation of the respondents' reaction may be due to, the effects of FGM, which vary from woman to woman. Some women might experience severe physical and mental health problems, while others may appear not to experience any side effect. In contrast, a study conducted in the UK reported that, nearly three quarters of the circumcised girls, who participated in the study, had the procedure performed safely by a doctor within a medical setting [48].

It cannot be ignored that, in the pretest, few respondents agreed that, there are types of FGM, where all types are harmful, and that the practice is illegal, as it can cause health complications like bleeding and bacterial infection. Unfortunately, it neither decreases sexual desire nor it is a religious commitment. In addition, the government is exerting efforts to combat the practice. Nonetheless, nearly three quarters of them shared an opinion that, the practice is tied to tradition. A possible explanation for these findings can be related to the respondents' confusion regarding the religious bases of the practice and ambiguity concerning the physiological mechanism for sexual activity. Additionally, some misconceptions regarding uncircumcised girls are still spreading in Arabian countries, as they can be hypersexual. However, almost all of them agreed upon the mentioned information in the posttest. In this perspective, Abdel Aziem [46] reported a low level of awareness concerning the types of FGM among the interviewed midwifes in his study in Eastern Sudan. Furthermore, one quarter of them claimed that, all types of FGM are harmful and three quarters of them reported that, FGM is a legal practice performed for cultural and religious purposes [47]. Moreover, more than half of them viewed that, FGM decreases sexual pleasure as well as the risk of HIV, and rather identified hemorrhage, infection and pain as potential risks. At the same time, two thirds of them will not circumcise their daughter in the future because of the mentioned complications. Similarly, more than half of male and female students, who participated in an Ethiopian study, knew that FGM has health risks, and the practice is mainly related to tradition, religious requirements and reduction of sexual desire [26]. 
Despite the WHO, which emphasized that males should be empowered through targeted reproductive health education and services related to FGM/C within the home, community and work settings [27]. Out of the blue, the respondents' husbands had no role in the decision of circumcising their daughters. This finding could be explained by the fact that men are usually excluded from women's reproductive health education and programs. As a matter of fact, men's attitudes toward women's reproductive health are not informed directly by health professionals [49]. In recognition of this, the WHO has made recommendations for the provision of information and services. Additionally, the majority of the respondents agreed that, men prefer to marry un-circumcised girls. The rationale for this opinion may be related to the perceived impact of FGM on sexual pleasure and desire. An Egyptian study conducted, reported that women who were circumcised had less sexual desire, fewer orgasms, and greater vaginal dryness during sex [50]. Conversely, in another study, Sudanese women believed that uncircumcised girls were less able to please their husbands sexually. This may reflect the notion that sexuality is purely a culture-related issue. This finding corresponds with that of Abathun, et al. [9] who found that, more than half of the male participants preferred to marry uncircumcised girls. Regarding safe practice or medicalization of FGM, it was supported by the respondents in the pretest and posttest [26]. In this regard, they suggested that, the practice should be performed in a hospital or a well-equipped clinic, by a doctor and an assisting nurse. This indicates that, they disagree on performing the procedure by unskilled personnel's. However, this opinion is not reassuring, as if they are unable to reach a specialized health professional, who accepts to perform a forbidden procedure, they will knock the doors of the traditional birth attendants and subject their daughters to many risks instead. Regarding the fourth hypothesis, it has been rejected, as findings showed that age and number of daughters were positively correlated with the attitude score, indicating that when age or number of girls increase, the attitude score increases as well in the direction of continuing FGM practice. Additionally, willingness to circumcise the respondents' daughters in the pretest was significantly associated with areas at which they were brought up and their educational level. This was clearly demonstrated through the higher prevalence among teachers with university education and who were grew up in urban areas. These associations can be attributed to the concerns of mothers regarding purity and chasity of their daughters, which increases when the number of girls increases. Moreover, decreasing girls' sexual desire either before or after marriage is of a great importance in Arabian Muslim countries, which can be attained through FGM as believed. Furthermore, although most of the mothers grew up in urban areas, yet they still held the same misconceptions and false beliefs, which they acquired from their rural origins. Surprisingly, attitudes toward FGM continuation were not significantly associated with respondents' previous circumcision. In fact, the effects of FGM vary from woman to woman, where some may experience severe physical and mental health problems, while others may lack any side effects. The other factor in the current study is the increased mean age $(36.93 \pm 8.42)$ of the respondents, which might be enough time to forget this bad experience, especially when no long-term complications were faced. Nonetheless, negative attitude towards FGM was significantly associated with previous circumcision, as reported by medical students, who participated in a previous Egyptian study [27].

\section{Conclusion and Recommendations}

The findings of this study revealed that, the respondents' knowledge and attitude towards FGM had improved after the implementation of the program from a fair level to good and from a neutral attitude to a negative one. This implies that, the educational program was effective in changing attitudes and replacing misperceptions of the study's respondents with correct information. Additionally, the respondents who support the continuity of FGM confirmed that if it is necessary, it should be done by trained health professionals and within safe clinical settings. Therefore, educational interventions on FGM/C are seen as a crucial source of empowerment for women, because it can promote their abilities to gather and assimilate information. Despite of the vast governmental efforts and anti-FGC interventions in Egypt, the practice of FGM is highly prevalent among the study's respondents, due to the sociocultural norms and behaviors. Despite the respondents' level of education and urban residency, some deep-rooted cultural and social beliefs still control their practices and misconceptions, which may constitute the fuel for the forces of continuity of such practice in Egypt. These sociocultural beliefs are making mothers, who are supposed to take care of their daughters, to expose them to danger instead. In conclusion, it is important to reinforce continuous awareness strategies given by health professionals in the community and work levels, in order to help females to be aware of the vast risks of FGM and to develop a negative attitude towards its continuation, especially when these females are teachers who are disseminating their knowledge, perceptions and attitudes to their students, who will be the future leaders of families that support the discontinuation of FGM/C at their homes. Mass media campaigns can raise awareness of the topic and provide accurate information and facts through popular communication Medias, such as radio, television programs and posters. Moreover, more interventions, aiming at empowering mothers about FGM and human rights, should be made, as such education will empower mothers and allows them to develop the skills and knowledge needed, leading to independent lives for their new generation, without violation of their rights. Hence, they will afford and equip them with correct information which will completely eradicate the practice of FGM in the future.

\section{Limitations of the Study}

Despite the important highlighted results of the current study, a limitation in form of small sample size will affect the generalizability of the results. Another limitation is the possibility of recalling biased information as the used tool was self-reporting tool of FGM/C. In addition to, using convenient sampling technique and absence of control group.

\section{Research's Clinical Implications}

Community-based interventions evidenced its effectiveness' in breaking the silence on FGM, raising awareness, allowing for open discussion and addressing all believes and misperception regarding FGM.

- Based on the obtained results and consistent with WHO, and UNICEF reports schools and government play an important role in ensuring implementation of targeted educational programs, including teacher-training and curriculum development which address FGM and related issues $[1,3]$.

- Within a multi-sectoral approach and collaborative efforts, education is critical as it can change and play a significant role in changing individual and societal views on FGM and challenging social and gender norms that promote gender equality in education also lay a foundation for empowering women and girls and their decision-making capabilities and self-sufficiency. 
Citation: Khalil AI, Orabi AM (2017) A Community-Based Intervention: Impact of an Educational Program in Exchanging Knowledge, Attitude, and Practices of Female Genital Mutilation (FGM). Health Care Current Reviews 5: 209. doi: 10.4172/2375-4273.1000209

- A collaborative support from ministry of education to integrate FGM into formal/non-formal education, as the topic is less of a taboo and young people can receive accurate information and precipitate negative attitudes toward continuity of FGM.

- Additional evaluative researches are needed to better understand the best way to identify the effective ways to implement educational programs that train healthcare workers in best practices for women living in regions supporting the practices of FGM.

- An understanding of the complex socio-cultural imperatives of this practice is important to guide government policies and should receive support from the Egyptian Parliament to support changes to the health care system and protect women and girls from this forceful practice.

\section{References}

1. UNICEF (2016) Female genital mutilation/cutting: A global concern. Geneva.

2. WHO (2016) Female genital mutilation: Fact sheet. Retrieved from World Health Organization.

3. Turner C (2016) When does child marriage become slavery? Retrieved from Girls not Brides.

4. Elgaali M, Strevens H, Mardh PA (2005) Female genital mutilation an exported medical hazard. Eur J Contracept Reprod Health Care 10: 93-97.

5. Al-Hussaini TK (2003) Female genital cutting - types, motives and perineal damage in laboring Egyptian women. Med Pinc Pract 123-128.

6. World Health Organisation (2016) Sexual and reproductive health: Health risks of female genital mutilation (FGM).

7. Albert J, Bailey E, Duaso M (2015) Does the timing of DE infibulation for women with type 3 female genital mutilation affect labor outcomes? BJM 23: 430-437.

8. UNICEF (2013) Female genital mutilation/cutting: a statistical overview and exploration of the dynamics of change.

9. Abathun AD, Gele AA, Sundby J (2017) Attitude towards the practice of female genital cutting among school boys and girls in Somali and Harari regions, Eastern Ethiopia.

10. Chesnokova T, Vaithianathan R (2010) The economics of female genital cutting. BE J Econ Analysis Policy.

11. Coyne CJ, Coyne RL (2014) The identity economics of female genital mutilation. J Dev Areas 48: 137-152.

12. Naguib K (2012) The effects of social interactions on female genital mutilation: Evidence from Egypt.

13. Ouedraogo S, KoissyKpein SA (2012) An economic analysis of female genita mutilation: How the marriage market affects the household decision of excision.

14. Molitor V (2014) Family economics in developing countries.

15. Bellemare MF, Novak L, Steinmetz TL (2015) All in the family: Explaining the persistence of female genital cutting in West Africa. J Dev Econ 116: 252-265.

16. Wagner $N$ (2015) Female genital cutting and long-term health consequences Nationally representative estimates across 13 countries. J Dev Stud 51: 226-246.

17. Camilotti G (2015) Interventions to stop female genital cutting and the evolution to the custom: Evidence on age at cutting in Senegal. J Afr Econ 133-158.

18. Nowak M (2008) Report of the Special Rapporteur on torture and other cruel, inhumane or degrading treatment or punishment.

19. World Health organisation (2017) Female genital mutilation: Fact sheet

20. Lee MJ, Strong N (2015) Female genital mutilation: What ob/gyns need to know? 60: 20-24.

21. Allen B, Oshikanlu R (2015) Female Genital Mutilation: A practical guide for health visitors and school nurses. Community Pract 88: 30-33.

22. World Health Organization (2016) Sexual and reproductive health: Classification of female genital mutilation.

23. Dawson A, Turkmani S, Fray S, Nanayakkara S, Varol N, et al. (2015) Evidence to inform education, training and supportive work environments for midwives involved in the care of women with female genital mutilation: A review of global experience. Midwifery 31: 229-238.

24. sustainabledevelopment.un.org/?menu=1300

25. Al-Khulaidi G A, Nakamura K, Seino K, Kizuki M (2013) Decline of supportive attitudes among husbands toward female genital mutilation and its association to those practices in Yemen. PLoS ONE 8.

26. Abolfotouh SM, Ebrahim AZ, Abolfotouh M A (2015) Awareness and predictors of female genital mutilation/cutting among young health advocates. Int $\mathrm{J}$ Womens Health 259-269.

27. Ahanonu E L, Victor O (2014) Mothers' perceptions of female genital mutilation. Health Educ Res 29: 683-689.

28. Alo OA, Gbadebo B (2010) Intergenerational attitude changes regarding female genital cutting in Nigeria. J Womens Health 20: 1655-1661.

29. GIZ (2011) Female genital mutilation and behaviour change.

30. The State of the World's Children Report (2016) UNICEF data: Monitoring the situation of children and women.

31. WHO (2008) Eliminating female genital mutilation: An interagency statement.

32. Mackie G, LeJeune J (2009) Social dynamics of abandonment of harmful practices: A new look at the theory.

33. UNICEF (2010) Innocent Insight. The dynamics of social change towards the abandonment of female genital mutilation/cutting in five African countries.

34. Shell Duncan B, Herniund Y (2006) Are there "stages of change" in the practice of female genital cutting?: Qualitative research findings from Senegal and the Gambia. Afr J Reprod Health 10: 57-71.

35. Gebremariam K, Assefa D, Weldegebreal F (2016) Prevalence and associated factors of female genital cutting among young adult females in Jigjiga district, eastern Ethiopia: A cross-sectional mixed study. Int J Womens Health 8: 357-365.

36. Toubia NF, Sharief EH (2003) Female genital mutilation: Have we made progress? Int J Gynecol Obstet 82: 251-261.

37. UNICEF (2005) Changing a harmful social convention: Female genita mutilation/cutting. UNICEF.

38. Badran I (1995) Knowledge, attitudes and practice the three pillars of excellence and wisdom: A place in the medical profession. 1: 8-16.

39. Mosby (2009) Mosby's Medical Dictionary.

40. Barber W, Badre A (1998) Culturability: The merging of culture and usability.

41. Bennett C (1976) Analyzing impacts of extension programs

42. Rahlenbeck S, Mekonnen W, Melkamu Y (2010) Female genital cutting starts to decline among women in Oromia, Ethiopia. Reprod Biomed Online 20: 867 872 .

43. Adewale OA, Taiwo GA (2015) Perception and attitude of pregnant women in a rural community north-west Nigeria to female genital mutilation. Arch Gyneco Obstet 291: 695-700.

44. Omolase C, Akinsanya O, Faturoti S (2012) Attitudes towards female genital cutting among pregnant women in Owo, Nigeria. S Afr Fam Pract 54: 363-366.

45. Afifi M, Bothmer M (2007) Egyptians women's attitude and believes about female genital cutting and its association with childhood maltreatment. Nurs Health Sci 9: 270-276.

46. Abdel Aziem AA (2012) Knowledge and attitudes of female genital mutilation among midwives in Eastern Sudan. Reprod Health 9: 23.

47. Hodes D, Armitage A, Robinson K, Creighton SM (2015) Female genital mutilation in children presenting to a London Safeguarding clinic: A case series. Arch Dis Child.

48. Saleem RA, Othman N, Fattah FH, Hazim L, Adnan B (2013) Female genital mutilation in Iraqi Kurdistan: Description and associated factors. Women Health 53: 537-551.

49. El-Defrawi MH, Lotfy G, Dandash KF, Refaat AH, Eyada M (2001) Female genital mutilation and its psychosexual impact. J Sex Marital Ther 27: 465-473.

50. Gruenbaum E (2006) Sexuality issues in the movement to abolish female genital cutting in Sudan. Med Anthropol Q 20: 121-138. 